\title{
Editorial
}

\section{The OECD Model and Controlled Foreign Company Regimes}

\author{
J. David B. Oliver, Coopers \& Lybrand, London
}

The increasing number of countries with controlled foreign company regimes gives rise to the question of the relationship of these regimes to the double tax treaty network. Where the regime is applied to pure tax haven countries, where no tax is levied, then there is unlikely to be a treaty and the question does not arise. However, increasingly the regime may apply to income which is nevertheless taxed in the foreign territory but the level of taxation is below a certain threshold. In such a case there may well be a treaty with the foreign territory and the question arises of the interaction of the regime and the treaty.

Let us take the case of a parent company with a directly owned foreign subsidiary. The starting point would be that under Article 7 the business profits of the controlled foreign company are not to be taxed in the territory of the parent company unless it carries on business there through a permanent establishment. Assume that there are no interest, dividends or royalties flowing between the two companies, aside from any dividends which the subsidiary may pay to its parent company. That leaves the Other Income Article (Article 21 ) which assigns the right of taxation to the country of residence of the subsidiary. In these circumstances why are the business profits of the controlled foreign company not wholly protected by the treaty from taxation by the home country?

One answer might be that it is because the provisions of Article 9 allow the home country to contend that conditions are imposed between the two enterprises which differ from those which would be made between independent enterprises so that profits accruing to the foreign enterprise may be included in the profits of the home enterprise and taxed accordingly. For example there is an interesting comment on Article 9 of the UK/US treaty in the US Treasury technical explanation. Article 9 in that treaty is not in the form of the OECD Model. Paragraph 4 is connected with the prohibition of formulary apportionment methods (but only at federal level). In commenting on para. 4 the technical explanation observes:-

'Finally, the prohibition contained in para. (4) will not apply where the enterprise doing business in a Contracting State is a resident of that State to the extent that it owns, directly or indirectly, the capital of a related enterprise. Thus, this provision does not affect the application of the United States 'subpart F' rules of code Sections 951-964'. This suggests that the writers of the explanation believed that (i) Article 9 permitted 'subpart F' rules to apply; (ii) para. 4 barring formulary apportionment might prevent their application; and therefore (iii) it was necessary to qualify the prohibition of formulary apportionment. One is nevertheless left puzzled and because the Article does not follow the Model the information is not a great deal of help in other cases.

It could be said that the question is a matter of the relationship of the treaties to domestic law. Where the domestic introduction of the controlled foreign company legislation was after the treaty then it could be said, in a particular territory, to override that territory's treaties. What about later treaties however: are these to be covered by a prospective over-ride? If not, then the question re-surfaces in the future.

Another discussion might focus on the mechanism for taxing the foreign profits. One way might be the calculation of a notional tax on the foreign profits which must then be paid by the parent company. Another way would be to deem profits to arise to the parent company. In either event the tax authority would be struggling to take the adjustment outside the provisions of Article 7 and bring it within the provisions of Article 9. In such a case it might however be argued that what is being attributed are particular items of income rather than business profits. However this approach would not be easy to reconcile with Article 21 (Other Income). Deeming a dividend to have been received by the parent company, on the other hand, could fall outside these provisions.

Much of the initiative for the introduction of controlled foreign company regimes has been 
driven by an understandable reluctance to tinker with residence definitions. It is also influenced by the flexibility and range properly afforded by pricing within an arm's length principle. If however Article 9, would not, say, allow a direct challenge to the pricing (where there are transactions directly between the parent and the subsidiary company) because they are at arm's length it seems curious that it should be possible, within the treaty provisions, to attack the foreign company's profits by the back door.

All of this suggests that it is now time for the relationship between controlled foreign company provisions and the OECD Model to be examined. The first work in this area was published last year under the title Pushing the Boundaries - The Interaction between Tax Treaties and Controlled Foreign Company Legislation. 'The premise of this pathfinder book, written by Daniel Sandler, is that controlled foreign company legislation is, per se, contrary to the OECD Model Convention.

Further analysis should now be taken up within the OECD because failure to do so could lead to a further 'help yourself' approach by tax authorities. It is one matter for a country to claim to attribute and tax income arising in tax haven, with no treaty, and taxed at a nil rate. It is quite a different matter for it to claim tax on income arising to a resident in another treaty country where it has borne tax: that is precisely what the OECD Model is intended to regulate.

Furthermore the problem can become compounded. A parent company with a controlled foreign company subsidiary may itself be acquired by a third country company. In such a case the subsidiary may then also be subjected to the controlled foreign company regime of the third country. It is not enough to reply that this is a triangular situation with which bi-lateral treaties are not well-suited to deal. At heart it is no more than an extension of the bilateral position which is equally unsatisfactory.

It would be helpful therefore if further analysis were pursued by the OECD on the relationship between the Model and controlled foreign company regimes with a view to determining how the Model does, or does not, over-ride their provisions. In the meantime it is of course open to a desperate taxpayer to challenge a controlled foreign company regime on the grounds that the subsidiary is protected by the Model treaty.

\footnotetext{
${ }^{1}$ Published by The Institute of Taxation in collaboration with The Institute for Fiscal Studies (£19.95).
} 